\title{
Online Peer Feedback as a Strategy to Improve Students' Translation Skills
}

\author{
Wahyu Diny Sujannah \\ English Language Education-Universitas Negeri Malang \\ Jl. Semarang 5 Malang,65145. E-mail:wahyudiny22@gmail.com
}

\begin{abstract}
The focus of this paper will be on giving feedback because it is essential to improve students' translation skills. Since some people sometimes find teacher feedback can make them down and lost their confidence to translate, peer feedback is chosen as a strategy to help the students to enhance their translation skills. With the advancement of ICT, this kind of strategy can be conducted as an outside class activity through online platforms. Hence, this paper aims to give ideas of implementing online peer feedback to improve students' translation skills as it also offers many benefits for the students.
\end{abstract}

Key Words: online peer feedback, ICT, translation skills

\begin{abstract}
Abstrak: Fokus penelitian ini adalah untuk menjelaskan pentingnya pemberian umpan balik untuk meningkatkan kemampuan penerjemahan siswa. Karena beberapa orang kadang-kadang merasa tidak termotivasi dan kehilangan kepercayaan dirinya dalam kemampuan menerjemahkan dari umpan balik yang diberikan oleh instruktur, maka umpan balik rekan dipilih sebagai strategi untuk membantu siswa meningkatkan keterampilan terjemahan mereka. Dengan kemajuan TIK, strategi semacam ini dapat dilakukan sebagai aktivitas luar kelas melalui platform online. Oleh karena itu, penelitian ini bertujuan untuk memberi gagasan tentang penerapan umpan balik rekan secara online untuk meningkatkan kemampuan penerjemahan siswa dimana selain itu umpan balik rekan secara online juga menawarkan banyak manfaat bagi siswa.
\end{abstract}

Kata kunci: umpan balik rekan online, TIK, keterampilan penerjemah

Instead of just changing words into another language, translating is actually mediating meaning of the words from the source language (SL) into the words from target language (TL). Translators need to make sure that the actual meaning of the words will not be changed or lost if they are transferred to another language. To be able to be a skilled translator, one needs to master other skills as well, such as "language acquisition, text competence, research competence, cultural competence, transfercompetence and abilities such as decision-making, creativity, to give quick responses" (Coban, 2015, p. 708). These kinds of skills are not easy to be mastered without any regular practice.

In translation class, teachers need to not only make students practice translating regularly, but also provide opportunities to give feedback, whether it is from them or the students themselves. Feedback is essential to improve students' translation skills since it can make them learn from their mistakes and guide them to the right track. In addition, it can also help them to develop their professional skills (Flanagan \& Heine, 2015) and make them self-regulated learners (Nicol and Dick, 2005). Mucha (as cited in Pietrzak, 2014) also states that proofreading is an essential sub competence for translators.

In fact, there are various kinds of feedback viewed from the ones providing it, namely self, peer, and teacher feedback. Nonetheless, regarding selffeedback, some people argue that it is difficult to be unbiased and to notice their own mistakes. In addition, they sometimes find teacher feedback can make them down and lost their motivation and confidence to translate. Hence, peer feedback is chosen as a strategy to help the students to enhance their translation skills. Hyland (2003) states that peer feedback usually comprise "assigning students to groups of two, three, or 
four who exchange completed first drafts and give comments on each other's work before they revise them" (p. 200). In this case, they need to share their works with each other, find the errors, and provide constructive feedback to improve the quality of their groupmates' translation.

In today's era, in which technology is often used and integrated to classroom, teachers can utilize Information and Communications Technology (ICT) to their teaching and learning process. Here, peer feedback can be conducted outside class through the use of online platforms, such as Edmodo, Google Docs, Facebook, WhatsApp, Wiki, and so on to make it timesaving instead of time-consuming. This strategy can be called as online peer feedback. Although this strategy is commonly practiced in writing class, it does not mean that teachers cannot carry it out in their translation class. They can just do it like in the writing class with some adjustments as the subject matter taught is different.

A few studies have unveiled the success of peer feedback-not only in a traditional classroom, but also in an online learning classroom-to improve students' translation skills. In a non-online learning environment, the results of a study conducted by Flanagan and Heine (2015) revealed that the students were empowered and have gained more from the task. Moreover, in an online learning environment, the findings of a study conducted by Wang and Han (2013) demonstrated that most of the participants realized that this strategy is valuable and beneficial to increase their translation skills.

Based on the issues explained above, this paper intends to share ideas about how to teach translation to English Foreign Language (ELT) students by using online peer feedback. This strategy is helpful to improve their translation skills.

\section{Implementation of Online Peer Feedback}

By implementing online peer feedback, the teaching and learning process will be student-centered as the students are the ones giving feedback to each other. Nevertheless, it does not mean that teachers will just do nothing and just look at their students do their works. They need to play an important role as a facilitator (Alfayyadh, 2016). They need to direct and help their students during the implementation of online peer feedback. Besides, they also need to monitor and check whether their students go to the right track or not.
In case the students are not familiar with online peer feedback, the teachers need to give introduction of online peer feedback first to make the students understand well. In this case, they can explain the definition ofonline peer feedback, theonline platform used to conduct it, the steps to conduct it, and its advantages. Furthermore, they can also describe the aspects that need to be given feedback. Here, they can provide feedback in the aspects of content (meaning transfer), organization, diction (vocabulary/technical term), grammar (language use/sentence structure), mechanics (spelling, punctuation, and capitalization). They can also give alternative translation or suggestions to their groupmates. Since everyone has different perspective and style in translating texts, so it is possible if they can give alternative translation.

Additionally, they need to explain the principles and give examples of a good feedback in front of the class. According to Nicol and Dick (2006), the principles of good feedback practice consist of helping clarify what good performance is (goals, criteria, expected standards), facilitating the development of self-assessment (reflection) in learning, delivering high quality information to students about their learning, encouraging teacher and peer dialogue around learning, encouraging positive motivational beliefs and self-esteem, providing opportunities to close the gap between current and desired performance, and providing information to teachers that can be used to help shape the teaching. As a result, the feedback given should be clear, effective, constructive, useful, meaningful, and so forth. The students cannot just give short complements such as "great", "good job", "marvelous!", "well done!", etc. or insults such as "poor work", "horrible translation", "full of errors", etc. to fulfill their obligation to give feedback. They need to provide reasons behind their judgments and give recommendations. For those who often give constructive feedback, they need to be given a bonus score to motivate them to provide useful suggestions to improve the quality of their groupmates' translation works.

In conducting online peer feedback, it will be better if they are given a peer feedback checklist or guideline sheet so that they can understand more on the aspects that need to be given attention. The teachers can browse the Internet to find the available checklists or guideline sheets or they can also develop it by themselves by following the principles and criteria of good feedback. On top of that, they need to train and give demonstration to the students on how to give feedback in an online platform. Regarding the online platform 
used, they can decide it by themselves or have discussion with the students first. They can choose between Edmodo, Google Docs, Facebook, WhatsApp, and Wiki or they may have other online platforms in mind. For the first implementation, they can carry this strategy out as an in-class activity. During its implementation, they need to monitor their students and help them to solve the occurred problems (if any). They can also check whether their students understand their instructions or not.

The followings are the steps in conducting online peer feedback as an outside class activity. First, the teachers give the students source texts in class. The source texts can be taken from either Bahasa Indonesia or English. Here, the students need to translate it individually in class. They can use the dictionary to translate the texts or look the meaning of the words in the internet. Second, the teachers assign the students into groups. Ideally, one group can consist of three to four students. In forming the groups, they can take the students' competence into account and mix the high, middle, and low achiever students so that they can learn from each other and help each other's learning. If they have not known the students' competence yet, they can conduct pre-test first before applying the strategy. Third, the teachers ask the students to conduct online peer feedback outside the class through the selected online platform. They can give the students the checklist or guideline sheet to ease them to give feedback. It will be better if they give the deadline for providing the feedback to give them time to analyze and value the students' feedback before the next meeting. In giving and receiving feedback, the students need to post their works in the selected online platform and ask their groupmates' to give constructive feedback there. Fourth, the teachers along with the students conduct a whole-class discussion. They can elicit students' feedback, discuss the students' most frequently occurred errors or mistranslations and ask the students the experienced difficulties in providing feedback and conducting online peer feedback. In the end, they have to help the students to cope with the difficulties and overcome the problems as well as giving comments assessing each student's strengths and weaknesses related to their works (Dollerup, 1994). Fifth, the teachers ask the students to revise their works and submit it to them. Here, the students have a freedom to choose whether they want to revise it based on their groupmates' feedback or not. If they think that the feedback is not helpful, they can ignore it.

\section{Benefits of Online Peer Feedback}

The students can get many benefits by applying online peer feedback. First, it can release anxiety and enhance students' confidence. As explained by Xing (2014), the students will feel relaxed and it will give them more "confidence and inspiration to speak out freely" (p. 375). In addition, their works will be given feedback first before being submitted, so they still have time to revise it first before giving it to the teachers. Second, it provides opportunities to learn from others' feedback and works outside the class. They can make relevant changes after outlining how their groupmates' works inspire them (Flanagan \& Heine, 2015). Third, it engages students into decision making process. Ching and Hsu (2013) argue that the students are intended to get maximum freedom to control their learning pace and make up their tasks. They also can decide whether they want to revise their translation based on their groupmates' feedback or not. Fourth, it develops students' critical thinking skills. The findings of a study conducted by Demirbilek (2015) showed that social media as a peer feedback tool increase critical thinking skills. Here, the students need to think critically to give feedback and to decide whether they want to revise their translation based on their groupmates' feedback or not. The last, it encourages students' collaboration. Xing (2014) argues that online peer feedback can be considered as a kind of collaborative and cooperative learning. It is because when providing feedback to each other, it opens chances for them to collaborate and cooperate with each other.

Based on the presented benefits above, it can be inferred that this strategy can be considered to be effective in improving students' translation skills.

\section{CONCLUSION}

Online peer feedback can be considered as an effective strategy to improve students' translation skills. It is due to the fact that it can release anxiety and enhance students' confidence, provide opportunities to learn from others' feedback and works, engage students into decision making process, develop students' critical thinking skills, and encourage students' collaboration. Therefore, it is suggested for English teachers that they implement this strategy as an outside class activity in teaching translation as it brings a great deal of benefits for the students. 


\section{REFERENCES}

Alfayyadh, H.M. (2016). The feedback culture in translator education: A comparative exploration of two distinct university translation programs (Doctoral thesis, Kent State University).Retrieved from https:/ /etd.ohiolink.edu/!etd.send_file?accession=kent 1460669418\&disposition=inline.

Ching, Y.H. \& Hsu, Y.C. (2013). Peer feedback to facilitate project-based learning in an online environment. The International Review of Research in Open and Distributed Learning, 14(5), 258-275.

Coban, F. (2015). Analysis and training of the required abilities and skills intranslation in the light of translation models and general theories oftranslation studies. Procedia-Social and Behavioral Sciences, 197, 707-714.

Demirbilek, M. (2015). Social media and peer feedback:What do students really thinkabout using Wiki and Facebook asplatforms for peer feedback?Active Learning in Higher Education, 16(3), 211-224.

Dollerup, C. (1994). Systematic feedback in teaching translation. In C. Dollerup \& A. Lingarrd (Eds.), Teaching Translation and Interpreting2, 121-132. Amsterdam: John Benjamins Publishing Company.
Flanagan, M. \& Heine, C. (2015). Peer-feedback as a translation training tool in web-based communication. Journal of Language and Communication in Business, 54, 115-136.

Hyland, K. (2003). Second language writing.Cambridge: Cambridge University Press.

Nicol, D.J. \& Dick, D.M. (2006). Formative assessment and self-regulated learning: A model and seven principles of good feedback practice. Studies in Higher Education, 31(2), 199-218.

Pietrzak, P. (2014). Towards effective feedback to translation students. inTRAlinea, Special Issue: Challenges in Translation Pedagogy, 1-9.

Wang, K.\& Han, C. (2013). Accomplishment in the multitude of counselors: Peer feedback in translation training, Translation \& Interpreting, 5(2), 62-75.

Xing, S. (2014). Application of online peer feedback in the teaching of college English writing. International Conference on Education, Language, Art and Intercultural Communication. Zhengzhou, Henan, China: Huanghe Science \& Technology College. Retrieved from https://www.atlantis-press.com/php/ download_paper.php?id $=12542$ 